\title{
Effect of Zinc Methionine Supplementation on the Growth Performance in Broilers
}

\author{
Faieza Arwa, Jonali Devi*, Kamal Sarma and Nazam Khan \\ Department of Veterinary Physiology and Biochemistry, FVSc \& AH, SKUAST-Jammu, \\ R.S. Pura-181102, UT of J \& K, India \\ *Corresponding author
}

A B S T R A C T

Keywords

Broiler, Growth, Supplementation, Zinc methionine

Article Info

Accepted:

12 May 2021

Available Online:

10 June 2021
Effect of zinc methionine supplementation on the growth performance in Vencobb strain broilers were studied from day old to 42 days. A total 240 broiler chicks were randomly divided into 3 groups. The broilers fed with basal diet were kept as control group (C), T1 group consists of the broilers fed with zinc methionine @ 45mg/kg in basal diet; and T2 group consists of broilers fed with zinc methionine supplementation @ $90 \mathrm{mg} / \mathrm{kg}$ of basal diet. Body weight was taken from day 1 to day 42 and feed intake, body weight gain and feed conversion ratio (FCR) were recorded from day 7 to 42 on weekly basis. All performance traits showed significantly $(\mathrm{P}<0.05)$ increasing trend with the advancing age. Zinc methionine supplementation in broilers significantly $(\mathrm{P}<0.05)$ enhanced body weight, feed intake, average body weight gain and improved FCR. From the present study, it can be concluded that zinc methionine can be used as a diet supplement for increasing the overall performance in broiler chicks during their growth period. Dietary supplementation of zinc methionine @ 45mg/kg is recommended in broilers for overall better performance.

\section{Introduction}

The poultry industry is one of the fast growing segments of Indian agricultural sector and therefore, plays a significant role in the Indian economy. From last three decades, poultry industry has made tremendous strides at the rate of $12-15 \%$ per annum in India. Today, India is the $18^{\text {th }}$ largest producer of broilers
(20 ${ }^{\text {th }}$ Livestock census, 2019). Among feed ingredients, trace minerals are highlighted, as they are essential for maintenance of physiological metabolism of poultry birds. Trace minerals generally act as a catalyst of wide variety of enzyme systems of the body and therefore, significantly affect growth performance and carcass characteristics. Among the trace minerals, zinc is present in 
all cells and participates in a wide variety of metabolic processes. It must be supplemented to the most diets of poultry to meet its nutritional requirements, because of the poor availability of zinc in plant feed ingredients. Zinc is a component of more than 300 different enzymes, transcription factors and cell signaling proteins that maintain the body's normal immune function, cell regulation and differentiation (Saleh, 2017). It is essential for growth, skeletal development and immune competence. Zinc deficiency in poultry has been shown to causes low growth, shortened and thickened legs with an enlarged hock and frizzled feathers.

To negate these effects, poultry diets are routinely supplemented with additional zinc. Traditionally, zinc supplementation in poultry feed was from inorganic sources, in the form of zinc sulfate $\left(\mathrm{ZnSO}_{4}\right)$ and zinc oxide $(\mathrm{ZnO})$, for reason of cost and availability. In recent years, organic zinc sources have been used progressively due to their potentially higher bioavailability (Salim et al., 2010). It has been documented that organic forms of zinc such as zinc picolinate and zinc methionine are more readily absorbed and bioavailable as compared to inorganic form (Sahin et al., 2005). Zinc methionine (ZnMet) is devoid of free divalent cations for chelation in the intestinal lumen with phytic acid. Therefore, it is metabolized in different methods which facilitate enhanced absorption of zinc (Burrel et al., 2004). In this context, Zinc-methionine could be advantageously incorporated in broilers diet at lower levels as compared to inorganic zinc for apprehending higher zinc higher bioavailability and lower excretion of zinc to the environment (Sunder et al., 2013). Available literature on the effect of zinc methionine on growth performance in broiler chicks is scant. Therefore, the present study was planned to observe the effect of zinc methionine at two different doses on the growth performance in broilers.

\section{Materials and Methods}

This study was designed to investigate the effect of various doses of zinc methionine as dietary supplement to assess growth performance in Cobb strain broilers. The investigation was conducted on 240 Cobb strain broilers in their growth phase from day old to 42 days. The experimental birds were divided in three groups. Control group (C): birds falling in this group were given the basal diet with no extra zinc supplementation.

Treatment-1 (T1): birds in this group were supplemented with zinc methionine@ @ 45 $\mathrm{mg} / \mathrm{kg}$ of the feed during study period and Treatment-2 (T2): birds in this group were supplemented with zinc methionine @ 90 $\mathrm{mg} / \mathrm{kg}$ of the feed during study period. The birds were provided formulated ration according to the feeding guidelines of NRC recommendations, 1994 (Table 1). Standard management practices were followed for proper maintenance of the broilers

\section{Parameters studied}

\section{Body weight}

All the broilers of each replicate group were weighed individually at the start of experiment and then at weekly intervals up to 42 days of age with the help of Mono pan balance and expressed in gram $(\mathrm{g})$.

\section{Feed Intake}

Feed consumption of experimental birds under each treatment group was calculated on replicate basis at weekly intervals for six weeks. For the purpose, daily feed offered to different groups was noted. At the end of every week, feed residue and spillage were collected and weighed and their amount was deducted from total feed offered to calculate the net feed intake. 


\section{Feed conversion ratio (FCR)}

Feed conversion ratio for a particular period was calculated from feed intake and body weight gain of that period by following formulae:

Feed conversion ratio

Feed consumed (g)

$=$

Weight gain $(\mathrm{g})$

\section{Body weight gain}

All the broilers of each replicate group were weighed individually at the start of experiment and then at weekly intervals up to 42 days of age with the help of Monopan balance and expressed in gram $(\mathrm{g})$.Body weight gain was then calculated as difference between final body weight and initial body weight.

For all the observed data in the present experiment, the standard statistical procedures recommended by Snedecor and Cochran (2004) have been followed. The data were presented by showing mean and standard error. The significant differences of values for different parameters studied were assessed by two-way analysis of variance. The data were analyzed under polynomial contrast and Duncan's post hoc multiple comparison at the significance level of 0.05 .

\section{Results and Discussion}

In the study, it could be seen that weekly body weight and feed intake increased significantly $(\mathrm{P}<0.05)$ in all the experimental groups of Cobb broiler chicks with advancement of age (Table 2). Feed conversion ratio (FCR) increased significantly $(\mathrm{P}<0.05)$ in control group from day 7 to 42 ; however, body weight gain increased significantly $(\mathrm{P}<0.05)$ from day 7 to 28 and then declined on day 35 and then increase was observed on day 42 . While in zinc methionine supplemented groups, the body weight gain of broiler chicks increased significantly $(\mathrm{P}<0.05)$ from day 7 to 21 and then declined on day 28 and again showed increasing trend up to day 42 . This might be due to increase in the edible components of broiler chicks accompanied by increase in edible weight and decrease in inedible weight and higher content of muscle tissue which is directly proportionate to age related changes. These findings coincide with the findings of many authors (Ao et al., 2006; Rehman et al., 2008, Sunder et al., 2008; Li et al., 2010), who also observed a linear increase in body weight with advancement of age.

In the study (Table 2), it was found that feed intake and body weight gain of Cobb strain broiler chicks were significantly $(\mathrm{P}<0.05)$ higher in zinc methionine supplemented groups when values were compared with that of the control group during the entire experimental period. $\mathrm{Zn}$ is known to be highly important for correct ossification and mineralization of the bone tissue (Scrimgeour et al., 2007). Depending on the dose, Zn affects bone metabolism and simulates boneforming processes, it stimulates the synthesis of DNA in osteoblasts and increases bone weight and the concentration of $\mathrm{Ca}^{+2}$ ions (Ma and Yamaguchi, 2000). Higher body weight in zinc supplemented groups might be due to increased feed intake and supplementation of zinc methionine which increases the rate of digestion and absorption in small intestine which is attributed to increased intestinal villi and epithelial height which in turn increases the digestion. Karmouz et al., (2011) and Sahoo et al., (2014) found that zinc supplementation was responsible for more than 300 enzymes which increase the activity of main digestive enzymes to work efficiently, thereby increasing the digestive enzyme synthesis in small intestine, which in turn increases the absorption which leads to better performance traits. Zinc intake above 
threshold induces intestinal metallothionein synthesis, is the zinc binding protein that is associated with increase zinc absorption. The study corroborated with the findings of Bun et al., (2011) and Zhou et al., (2010). A similar finding was also reported by Abas et al., (2020), who showed that addition of zinc to the broiler chicks resulted in significant $(\mathrm{P}<0.05) \quad$ improvement of growth performance. In an another finding reported by Tronina et al., (2007) showed that at 21 day, the body weight of chicken receiving zinc oxide was lower by approximately $2 \%$ compared to chicken received zinc-glycine; while on 42 day, the birds receiving $\mathrm{ZnO}$ had significantly higher body weight than zincglycine fed group. Midilli et al., (2014) found that the supplementation with organic and inorganic zinc alone or in combination significantly $\quad(\mathrm{P}<0.05) \quad$ increased the digestibility of $\mathrm{Zn}$ in the male broilers; supplementation of diet with zinc propionate @ $75 \mathrm{mg} / \mathrm{kg}$ along with phosphorus or Zinc sulfate@75mg/kg of diet with phosphorus increased the body weight, body weight gain and enhanced the feed conversion ratio in broilers.

However, Iqbal et al., (2011) reported that feed intake of broiler chickens were not significantly influenced by supplementation of zinc irrespective of their sources.

Similarly, Ezzati et al., (2013) observed that $100 \mathrm{mg} / \mathrm{kg}$ of zinc in diet has no effect on feed consumption when compared to control. Midilli et al., (2014) also reported same findings in regards to mean feed intake in broilers.

In the study (Table 2), FCR was found significantly $(\mathrm{P}<0.05)$ higher in control group when compared with zinc methionine supplemented groups. The positive of effect of zinc supplementation on feed conversion ratio may be attributed to the improvement in the nutrient digestibility and efficiency for better utilization of nutrients that enhances the feed conversion ratio.

Zinc has a protective role on the pancreatic tissue against oxidative damage, thus helping the pancreas to function properly including the proper secretion of digestive enzymes, thus improving the digestibility of nutrients and consequently the performance. The findings of Ahmadi et al., (2013) also showed a decrease in FCR at $60 \mathrm{mg} / \mathrm{kg}$ supplementation of Zinc oxide nanoparticles.

When comparing between zinc supplemented broiler chicks @ 45mg/kg (T1) and 90 mg/kg of diet $(\mathrm{T} 2)$, significantly $(\mathrm{P}<0.05)$ higher body weight was recorded in T2 on day 28 and 35 when compared to T1. Significant $(\mathrm{P}<0.05)$ difference was observed in feed intake between the group from 21 to 35 day.

While, no significant difference was found between $\mathrm{T} 1$ and $\mathrm{T} 2$ throughout the experimental period except day 14 in case of FCR and day 28 in case of body weight gain (Table 2).

Bun et al., (2011) conducted a study to investigate growth performance and zinc utilization during the life cycle of broilers when diets were supplemented with various concentrations of zinc from two different sources and found that optimum body weight gain was achieved by $80 \mathrm{mg} / \mathrm{kg}$ zinc supplementation, which was in harmony with our results.

Norouzi et al., (2013) investigated the effects of different dietary levels of zinc acetate $(0,30$ and $60 \mathrm{mg} / \mathrm{kg}$ ) on performance traits and blood antioxidant status of broilers under heat stress conditions and found the inclusion of 30 $\mathrm{mg} / \mathrm{kg}$ zinc resulted in increase in performance traits (body weight gain and the average feed intake). 


\section{References}

Abas, W. F., Nadia N. Al-Hajo, A., Shlij, A. A., Al Mjbel and Abdul wahid, A. S. 2020. Zinc-Methionine and it's effect on chicken meat quality. Plant Archives. 20 (1): 1389-1394.

Ahmadi, F., Ebrahimnezhad, Y., Sis, N. M. and Ghiasi, J. 2013. The effects of zinc oxide nanoparticles on performance, digestive organs and serum lipid concentrations in broiler chickens during starter period. Intl. J. Biosci., 3:23-9.

Ao, T., Pierce, J. L., Dawson, K. A., Power, R., Pescatore, A. J., Cantor, A. H. and Ford, M. J. 2006. Evaluation of bioplex Znasan organic zinc source for chicks. International J. Poultry Sci. 9: 808-811.

Bun, S., Guo, Y., Guo, F. and Cao, H. 2011. Influence of organic zinc supplementation on on the antioxidant status and immune responses of broilers challenged with Eimeriatenella. Poultry Sci. 9: 12201226.

Burrell, A. L. Dozier, W. A. Davis, A. J. Compton, M. M. Freeman, M. E. Vendrell, P. F. Ward T. L. 2004. Responses of broilers to dietary zinc concentrations and sources in relation to environmental implications. British Poultry Sci., 45: 255-263

Ezzati, M. S., Bozorgmehrifard, M. H. and Bijanzad, P., Roooasoulinezhad, S., Hamed, M., Faramarzi, S., Ghaedi, A., Ghabel, H. and Stabraghi, E. 2013. Effects of different level of zinc supplementation on broilers performance and immune response to Newcastle disease vaccine.Euro. J. Exp. Biol. 3 (5): 497-501.

Iqbal, S., Deo, C., Mandal, A. B., Praveen, K. and Wachat, V. B. 2011. Response of feeding different sources and concentrations of zinc and copper on performance of broiler chickens. Indian J. Poult. Sci. 46 (3):330-336.

Karamouz, H., Ghiasi, J., Zadeh Adam Nezhad, H., Ebrahim Nazhad, Y. and MaheriSis, N. 2011. Effect of different levels of zinc oxide supplement on mucosal lucineaminopeptidase enzyme activity in small intestine of male broiler chicks. Int. J. Anim. Vet. Adv. 3 (2): 54-57.

Li Y., Wang, C., Zhu, K, Feng, R. N. and Sun, C.H. 2010. Effects of multivitamin and mineral supplementation on adiposity, energy expenditure and lipid profiles in obese Chinese women. Intl. J. Obesity, 34(6):1070-1077.

Ma, Z. J. and Yamaguchi, M. 2000. Alternation in bone components with increasing age of newborn rats: role of zinc in bone growth. J. Bone and Mineral Metabol. 18: 264-270.

Midilli, M., Salman, M., Muglali, O. H., Ogretmen, T., Cenesiz, S. and Ormanci, N. 2014. The effects of organic or inorganic zinc and microbial phytase, alone or in combination, on the performance, biochemical parameters and nutrient utilization of broilers fed diet low in available phosphorus. Ind. J. Food Agricul. Vet. 8:461-467.

Norouzi, E., Daneshyar, M. and Farhoomand, P. 2013. Dietary supplementation effects of zinc acetate and magnesium sulfate on performance and antioxidant status of broilers under continuous heat stress. Spanish J. Agri. Res. 11: 127131.

Rehman, H., Böhm, J. and Zentek, J. 2008. Effects of differentially fermentable carbohydrates on the microbial fermentation profile of the gastrointestinal tract of broilers. $J$. Anim. Physiol. and Anim. Nutrition. 92: 471-480. 
Sahin, K., Smith, M. O., Onderci, M., Sahin, N., Gursu, M. F. and Kucuk, O. 2005. Supplementation of zinc from organic or inorganic source improves performance and antioxidant status of heat distressed quail. Poult Sci. 84: 882-887.

Sahoo, A., Swain, R. K. and Mishra, S. K. 2014. Effect of inorganic, organic and nanozinc supplemented diets on bioavailability and immunity status of broilers. Int. J. Adv. Res. 2 (11): 828837.

Saleh, A. A., Ragab, M. M., Ahmed, E. A. M., Abudabos, A. M. and Ebeid, T. A. 2017. Effect of dietary zincmethionine supplementation on growth performance, nutrient utilization, antioxidative properties and immune response in broiler chickens under high ambient temperature. J. Applied Anim. Res. 46 (1): 820-827.

Salim, H. M., Lee, H. R., Jo, C., Lee, S. K., Lee, B. D. 2010. Effect of sources and levels of $\mathrm{Zn}$ on the tissue mineral concentration and carcass quality of broilers. Avian Biol. Res. 3: 23-29.

Scrimgeour, A. G., Stahl, C. H. H., McClung, J. P., Marchitelli, L. J., Young, A. J.,
2007. Moderate zinc deficiency negatively affects biomechanical properties of tibiae independently of body composition. J. Nutritional Biochem. 18 (12): 813-819.

Snedecor, G. W. and Cochran, W. G. 2004. Statistical Methods, 8 Edn., Oxford and IBH Pub. Co., Kolkata.

Sunder, G. S.; Kumar, C. V; Panda, A. K.; raju, M. V. L. N. and Rama Rao, S. V. 2013.Effect of supplemented $\mathrm{Zn}$ and Mn on broiler performance, Bone measures, tissue mineral uptake and immune response at 35 days of age. Current Res. in poultry Sci. 3(1): 1-11.

Tronina, W. Kinal, S and Lubojemska, B. 2007 Effect of various forms of zinc applied in concentrate mixtures for broiler chickens on its bioavailability as well as meat composition and quality. Poland J. Food and Nutritional Sci. 57 (Suppl. 4C): 577581.

Zhou, X., Wang, Y., Gu, Q. and Li, W. 2010. Effect of dietary probiotic, Bacillus coagulans, on growth performance, chemical composition, and meat quality of Guangxi yellow chicken. Poult. Sci. 89: 588-593.

\section{How to cite this article:}

Faieza Arwa, Jonali Devi, Kamal Sarma and Nazam Khan. 2021. Effect of Zinc Methionine Supplementation on the Growth Performance in Broilers. Int.J.Curr.Microbiol.App.Sci. 10(06): 434-439. doi: https://doi.org/10.20546/ijcmas.2021.1006.046 